\title{
EDUCAÇÃO ESCOLAR E DÍVIDA SIMBÓLICA: \\ reflexões sobre a (des) caracterização da escola e da docência
}

Jenerton Arlan Schütz:
Fábio César Junges

Resumo

O presente artigo, de cunho bibliográfico, tematiza a relação intrínseca entre educação escolar e dívida simbólica, dívida que todos os professores devem ou ao menos deveriam assumir face às gerações vindouras. No entanto, há teorizações e discursos que negam a tarefa de assumir a dívida simbólica, e com isso, desescolarizam a própria escola e instauram a demissão do professor enquanto representante do mundo adulto. Nesse sentido, num primeiro momento, apresentam-se as teorizações e discursos que abandonam e negam a dívida simbólica na tarefa educacional; num segundo momento, aborda-se a imprescindibilidade de se assumir e "pagar" a dívida simbólica da qual somos devedores, fazendo jus à especificidade da educação escolar e da docência. Entendese, portanto, que a educação escolar tem em sua especificidade a filiação simbólica das novas gerações ao mundo comum, e no interior da escola, só o professor poderá saldar esta dívida.

Palavras-chave: docência; escola; mundo comum.

\section{SCHOOL EDUCATION AND SYMBOLIC DEBT: reflections on the (de) characterization of school and teaching}

\section{Abstract}

This bibliographic article discusses the intrinsic relationship between school education and symbolic debt, a debt that all teachers should or at least should face in the face of future generations. However, there are theories and speeches that deny the task of assuming the symbolic debt, and with that, unschool the school itself and establish the dismissal of the teacher as a representative of the adult world. In this sense, at first, the theorizations and discourses that abandon and deny the symbolic debt in the educational task are presented; in a second step, it addresses the necessity of assuming and "paying" the symbolic debt of which we are debtors, living up to the specificity of school education and teaching. It is understood, therefore, that school education has in its specificity the symbolic affiliation of new generations to the common world, and within the school, only the teacher will be able to pay this debt.

Keywords: teaching; school; common world.

\section{EDUCACIÓN ESCOLAR Y DEUDA SIMBÓLICA:} reflexiones sobre la (des) caracterización de la escuela y la enseñanza

\section{Resumen}

Este artículo bibliográfico analiza la relación intrínseca entre la educación escolar y la deuda simbólica, una deuda que todo docente debería o al menos debería afrontar de cara a las generaciones futuras. Sin embargo, existen teorías y discursos que niegan la tarea de asumir la deuda simbólica, y con ello, desescolarizar la propia escuela y establecer el despido del docente como 
representante del mundo adulto. En este sentido, en un primer momento, se presentan las teorizaciones y discursos que abandonan y niegan la deuda simbólica en la tarea educativa; en un segundo paso, se aborda la necesidad de asumir y "pagar" la deuda simbólica de la que somos deudores, a la altura de la especificidad de la educación y la enseñanza escolar. Se entiende, por tanto, que la educación escolar tiene en su especificidad la afiliación simbólica de las nuevas generaciones al mundo común, y dentro de la escuela, solo el docente podrá pagar esta deuda.

Palabras clave: docencia; colegio; mundo común.

\section{INTRODUÇÃO}

A tarefa educacional se renova a cada adentrar de uma nova criança no mundo humano. Ou, no dizer de Arendt (2013), a razão de ser da educação está no fato de das crianças nascerem para o mundo. Por isso mesmo que compreender o legado deixado por aqueles que chegaram antes de nós nesse mundo configura, fundamentalmente, o campo educacional, em dois sentidos: a) educa-se as gerações que chegam a partir daquilo que representam as nossas percepções sobre o desejável - herdadas pelo diálogo com as gerações que nos antecederam - sobre o humano e o mundo humano, com o intuito de que as gerações compreendam a condição humana; b) educa-se as novas gerações a partir de uma herança histórica não objetivada em nenhum testamento registrado em cartório.

Inaugura-se, nesse sentido, uma responsabilidade tácita de todos os adultos, responsáveis pela familiarização das gerações vindouras com o legado humano. É possível vir a falar sobre a educação pelo fato de se acreditar que a educação pode oferecer uma orientação em direção à humanidade e que permite a cada um dos recém-chegados a encontrar um lugar no mundo. Por isso, "[...] o homem não pode se tornar um verdadeiro homem senão pela educação" (KANT, 1999, p. 15). Este é o motivo que leva uma geração a educar a outra e só é possível porque uma geração recebe tal educação de outra, num movimento de continuidade, durabilidade e cumplicidade. Logo, quando se tematiza a educação escolar sempre está suposto o desejo de que o mundo humano, construído pelas gerações anteriores, possa se tornar durável, habitável e digno para aqueles que chegam e chegarão neste mundo.

Além disso, acredita-se que o mundo humano, com as suas linguagens, técnicas, valores, obras, etc., constitui um legado que merece ser preservado e apresentado para a novas gerações, a fim de que elas aprendam as linguagens e conheçam as obras que a história humana construiu. Logo, torna-se possível educar as novas gerações porque o mundo foi e é produzido e concebido por nós como fruto concreto de nossas ações e fabricações. No momento em que se educa as crianças se está a permitir que aquilo que nos foi legado pelas gerações anteriores possa permanecer, ligando-nos a elas e mediando as nossas ações e relações.

Nessa direção, pode-se considerar que a geração adulta está sempre em dívida para com aqueles que chegam e chegarão neste mundo, uma dívida, por assim dizer, fundamentalmente simbólica. Uma dívida que se assenta na preocupação, responsabilização e comprometimento por parte dos adultos e de todos aqueles que se ocupam da educação das novas gerações.

Contudo, num primeiro momento, o presente artigo apresenta teorizações e discursos que caminham na contramão de saldar esta dívida, que transferem, inclusive, a dívida para as novas gerações, com isso, deixando-as à própria sorte e instaurando a desresponsabilização - por parte dos adultos e responsáveis -, denominamos estes de maus pagadores. Por analogia, indaga-se: é possível quitar uma dívida sem ter saldo? Como saldar uma dívida sem ter recebido a conta ou então ter o conhecimento da mesma? Como saldar uma dívida sem sequer ser "iniciado" na mesma? 
Aliás, por que alguém se torna professor? Por que alguém decide se dedicar à educação escolar? $\mathrm{O}$ que faz um professor ser professor?

As indagações acima serão o mote da segunda parte deste artigo. A partir delas, busca-se tematizar a importância de os adultos - professores, pais, responsáveis- assumirem a dívida simbólica da qual são devedores, com o intuito de saldá-la. Saldar corresponde à possibilidade de as novas gerações não precisarem iniciar da estaca zero - sem saldo -, uma vez que há alguém nesse mundo que é anterior a elas e que já incorporou e se tornou íntimo do mundo comum, sendo permitido que inicie os novos nesse legado, filiando-os simbolicamente ao mundo. A educação, portanto, é um processo que filia os novos em uma tradição comum, instalando-os, também, numa condição de devedores. Só assim se torna razoável garantir um passado para o futuro.

\section{A NEGAÇÃO DA DÍVIDA SIMBÓLICA: REFLEXÕES SOBRE OS MAUS PAGADORES}

Pode parecer estranho ter que defender que todos os adultos são responsáveis por aqueles que recém chegam ao mundo. Contudo, se o fazemos, é porque há uma ruptura, um ofuscamento desta percepção, consciente ou não, de modo que a negação da dívida simbólica pode ocorrer de diversas formas e em diferentes espaços, configurando o mundo adulto de mau pagador. Ser um mau pagador, nesta perspectiva, constitui-se num dos modos e meios de se negar o mundo humano, a responsabilidade enquanto adultos, a responsabilidade enquanto professores e representantes do mundo e, com isso, a negação da própria infância.

À luz das reflexões de Masschelein, Simons (2014; 2017), Arendt (2013), Guillot (2008), Lajonquière (1999; 2009) e outros interlocutores, são fundamentadas as perspectivas que se recusam a assumir a responsabilidade face às novas gerações e o mundo humano comum. Tratase, nesse sentido, de um movimento um tanto quanto difícil, uma vez que é preciso reunir as teorizações do âmbito educacional e investigar as contribuiçoes para aquilo que ser característico da conjuntura dos maus pagadores.

A análise da situação da educação no Brasil, especialmente no que se refere ao desempenho das escolas, frequentemente é feita com base num comparativo com a situação das escolas em outros países (Finlândia, Inglaterra...), sugerindo-se, então, que o problema da escola brasileira se deve ao "atraso" de nossas práticas e concepções educacionais. Disso resulta, em regra, a indicação de que é preciso inovar e renovar mais e mais, buscar novidades e, até mesmo, abandonar nossas visões e práticas para assumir algo mais moderno, capaz de trazer um desempenho mais satisfatório por parte das escolas brasileiras.

Contudo, esse raciocínio merece um pouco mais de atenção. Arendt, ao escrever sobre a crise da educação nos Estados Unidos durante a década de 50, apresenta algumas reflexões que podem ajudar a pensar os nossos problemas. Segundo Arendt (2013, p. 227-228),

[...] a resposta à questão [...] - Por que os níveis escolares da escola americana média acham-se tão atrasados em relação aos padrões médios na totalidade dos países da Europa? - não é, infelizmente, simplesmente o fato de ser este um país jovem que não alcançou ainda os padrões do Velho Mundo, mas, ao contrário, o fato de ser este país, nesse campo particular, o 'mais avançado' e moderno do mundo. E isso é verdadeiro em um dúplice sentido: em parte alguma os problemas educacionais de uma sociedade de massas se tornaram tão agudos, e em nenhum outro lugar as teorias mais modernas no campo da Pedagogia foram aceitas tão servil e indiscriminadamente. 
Talvez mais aqui do que nos Estados Unidos, as instituições educacionais parecem sempre predispostas a aderir de forma servil e indiscriminadamente as teorias mais modernas, as metodologias salvadoras/inovadoras, entre outras panaceias que prometem revolucionar o ensino, enfim a toda sorte de pedagogismos, enquanto paixão desenfreada pelo novo.

A escola, desse modo, está despojada de qualquer sentido intrínseco. Ela fica à mercê da ilusão pelo "pathos do novo"1. Ilusão de que se nutrem as modernas teorias educacionais, com frequência constituídas de uma impressionante miscelânea de bom senso e absurdo, cujo propósito é revolucionar todo o sistema educacional. Nessa direção, o novo e sua novidade são revestidos de positividade e entendidos como avanço, enquanto os saberes da tradição (a transmissão) são considerados ultrapassados e inúteis.

Nessa direção, enuncia-se sempre a mesma chantagem de que os tempos mudaram, de que entramos em um novo paradigma, da adaptação ao novo e ao inevitável. Essa paixão desenfreada por aquilo que é novo e redentor apresenta pressupostos problemáticos. O mais conhecido deles refere-se ao ensino centrado na criança, o que corresponde trabalhar segundo o interesse e a necessidade da criança. O slogan que marca essa tendência ficou conhecido como "nós não ensinamos matérias, ensinamos crianças", como se o ato de educar significasse formar crianças independentemente de ensiná-las conteúdos escolares.

Atualmente, as instituições e os ideais, obviamente, perderam muito de seu significado, e a transferência de conhecimento e a educação centrada no professor estão fora de moda. Exatamente por causa disso, as escolas modernas estão sendo convertidas em ambientes de aprendizagem centrada no aluno. [...]. Faz isso, efetivamente, por não apresentar nada e dizer: "Sente-se à mesa, experimente as coisas, e eu, como seu facilitador de aprendizagem, irei ajudá-lo" (MASSCHELEIN; SIMONS, 2017, p. 107).

Em decorrência disso, verifica-se um declínio crescente dos conteúdos, das disciplinas e dos conhecimentos que fazem uma diferença na vida do aluno. O professor passa a ser visto como aquele que respeita, ama e considera a criança, concentrando-se em criar ambientes pedagógicos.

Já é comum alegar que o professor é um facilitador de aprendizagem, ou ainda, um mediador do processo de construção do conhecimento. Entretanto, propõe-se ainda que cada aluno é capaz de construir o seu próprio conhecimento a partir de experiências próprias. Logo, cabe ao professor facilitador envolver o aluno enquanto protagonista de sua aprendizagem e deixar de ser apenas uma fonte de informação e conhecimento. Com isso, assume-se que o conhecimento e a compreensão são ativamente construções do aluno e não do professor para o aluno. Em consonância, para Schütz (2017, p. 50), nesta perspectiva

[...] o aluno seria o autor principal da construção do conhecimento, isto é, por sua própria capacidade de raciocínio o aluno estaria apto para construir o conhecimento, desenvolver suas habilidades e resolver seus problemas. Resta ao professor se tornar um sujeito de vários adjetivos: um animador, um apresentador, um simples colaborador ou corriqueiramente denominado de facilitador de todo processo. Recebe os adjetivos pois nessa modalidade de ensino e aprendizagem o que se deve levar em consideração é o aluno, seu desenvolvimento, sua aprendizagem, estando todo o processo de aprendizagem centrado no aluno e no seu potencial de habilidades.

1 Pathos do novo é um conceito utilizado por Arendt (2013) para denominar o afã das sociedades modernas pelo novo e o consequente rechaço ao velho (tradição). 
No entender de Guillot (2008), quando Rogers transpôs as suas ideias para o âmbito educacional, com a sua obra Liberdade para Aprender (ROGERS, 1971), surgiram inúmeras confusões e amálgamas: a criança passa a ser a dona de suas aprendizagens. Rogers (1971) pensava a relação pedagógica e criticava os denominados métodos "verticais" de transmissão dos saberes, alheios às reações dos alunos.

A partir disso, tem-se pensado e procurado instaurar, como lembra Guillot (2008), uma educação livre de interditos, uma espécie de sociedade sem escola, comunidades de crianças em autodeterminação, etc. Aos poucos os adultos, responsáveis, lavam as mãos e se tornam indiferentes.

Não obstante, nos dias de hoje, não são poucos os adultos que se comportam mais como porteiros das veleidades do que como guias da verdade em relação às crianças. Para Guillot (2008), essa espécie de não-diretivismo é uma errância que, em nome da criança, lhe delega escolhas que, mesmo que expressem seu desejo, a abandonam a responsabilidade ilusória e àqueles que se encarregarão de retomá-la por sua conta.

Em síntese, a criança passa a ser o centro do processo de ensino e aprendizagem. $\mathrm{O}$ ato educativo passa a ser marcado pela simetria pedagógica, ou seja, professor e criança estão no mesmo nível - dado que o professor (adulto) deve seguir as crianças e pouco (ou nada) ensinar a elas -, o professor é um companheiro que estimula, acompanha, facilita e anima. Nesta perspectiva, a construção dos conhecimentos se dá pela criança, é ela que os constrói, é ela que os organiza e decide quando e onde aprender. Ela constrói, extrai e abstrai seu conhecimento por meio de uma ação de observação ou da experiência da realidade. Transfere-se o ponto arquimediano para a criança.

Se a criança é o centro do processo educacional, significa que a espontaneidade infantil deve ser preservada pelo professor a todo custo. O papel do professor deixa de ser o daquele que ensina para ser o de auxiliar a criança em seu próprio processo de aprendizagem, ou seja, o professor deve se lembrar de que na realidade não ensina, mas ajuda a criança a aprender, sempre partindo de uma indagação ou necessidade da criança. Isso tem a ver com o que afirma Malaguzzi (1999, p. 83), ao se referir aos professores, considera que estes devem "[...] aprender a nada ensinar às crianças, exceto o que podem aprender por si mesmas".

Com isso, o conhecimento espontâneo e cotidiano é mais importante que o conhecimento construído histórica e culturalmente pela humanidade, aliás, não apenas o protagonismo, mas também a capacidade da criança de significação própria do mundo e de produzir cultura. Não há, desse modo, espaço para a falta, já que a criança é plena ${ }^{2}$.

Como consequência, não raras vezes as crianças consideram ou acham que não necessitam da mediação do tempo. Possuem a sensação de que mundo só ou já começou com elas, que não precisam da palavra de alguém mais velho, de um professor. Nas palavras de Larrosa (2018, p. 76),

É muito difícil (quase impossível) criar uma atmosfera na aula na qual o
protagonista não seja nem aluno nem professor, mas o texto (e a através do texto,
o mundo, o assunto: o que dá a falar, dá a penar, aquilo para que o texto indica).
Meus alunos já se formatam (formataram) em uma escola que lhes diz que eles
são os protagonistas, que o mais interessante que há na aula é eles mesmos. Já
cresceram em um mundo que não reconhece nenhuma autoridade ou a que se
reconhece é a do próprio umbigo, isso que Ferlosio chamava de "onfaloscopia".

2 Qual seria o princípio da identidade para se impor neste caso, “uma coisa é ou não é”? Logo, não tem espaço para se pensar a ambiguidade de uma situação como a infância. Pensa-se por absolutos, sem gradiente. 
Para Lajonquière (1999), essa inversão do eixo educativo implica na renúncia ao próprio ato educativo, bem como alimenta todo tipo de manifestação de camaradagem simpática. $\mathrm{O}$ interesse em se ajustar a intervenção a um suposto estado natural das capacidades dos alunos implica na renúncia ao ato. Isto é, implica na demissão do adulto da posição de educador e responsável pelas novas gerações. Em suma, "o adulto atua como um servidor obediente aos mandatos naturais que apontam tornar real um ideal de natureza"” (LAJONQUIÈRE, 1999, p. 36).

Nessa direção, um adulto (pai, professor, responsável) cada vez que se endereça às crianças ou aos alunos, abriga o medo de vir a estragar a natureza, ir contra a natureza. Não obstante, a criança passa a ser pensada sob o viés de cliente e a educação escolar é tida como um processo pelo qual se deve "[...] outorgar-lhe aquilo que precisa para sua satisfação total, pois, como sabemos, 'o cliente sempre tem razão" (LAJONQUIÈRE, 1999, p. 36).

A escola, tal como defendida por Masschelein e Simons (2017), perde o seu significado e passa a ser domada pelas modas da vez. Outrossim, os adultos dão as costas ao passado, esquecemse de se endereçarem à criança, ao aluno, em nome de uma dívida simbólica, isto é, "[...] cuidá-la em virtude da manutenção de uma tradição filiatória, cuja contingência 'cuidou' necessariamente dele mesmo, e não pelo ganho narcísico - e, portanto, mina os próprios fundamentos do ato" (LAJONQUIÈRE, 1999, p. 42).

A escola, nos dias de hoje, passa a ser domada a ensinar conhecimentos utilitários, conforme as próprias necessidades atuais ou futuras, quanto de tornar natural o aprendizado, com vista ao usufruto da felicidade "natural" à infância. "Trata-se de uma empresa movida pelo imediatismo da satisfação" (LAJONQUIÈRE, 1999, p. 84). Antes, como lembra Lajonquière (1999), a escola se sustentava justamente na veiculação da promessa de as crianças virem a usufruir num futuro o lugar existencial de adulto. Entretanto, hoje, tanto o ensinado quanto o ato de ensinar valem apenas na proporção do gozo imediato.

Para Lajonquière (2009, p. 175), “[...] a renúncia dos velhos ao ato de educar é uma forma de infanticídio". Alforriar/liberar uma criança, é impedi-la de viver a própria infância, de ser criança. Ao se assumir tais pressupostos incorre-se na desescolarização da própria escola e na descaracterização do próprio professor enquanto fonte de autoridade de que a criança tanto precisa para se desenvolver. A escola se transforma em um lugar de vida, aberto ao sujeito interior e ao mundo exterior, o professor se torna um mediador, animador, facilitador, etc., ele não deve usar os seus conhecimentos, exige-se dele que deixe as crianças livres aos desejos e anseios.

Daí a insistência, igualmente comum, de que as práticas escolares sejam organizadas de forma a minimizar a interferência exterior às crianças e a fomentar sua livre escolha. Nessa perspectiva, o elo entre educação e "liberdade" manifesta-se por meio do cultivo de vivências escolares nas quais os alunos são alegadamente concebidos como protagonistas do ato educativo: assembleias que determinam as regras de convivência, a escolha de percursos formativos a partir de seus interesses e outras medidas análogas, que visariam reduzir ou eliminar o caráter rígido de um processo de escolarização fundado em modelos centrados no "mundo adulto" ou em um "currículo tradicional" e fomentar a autonomia individual (CARVALHO, 2010, p. 846).

Ademais, a escola não existe primariamente para as crianças, mas para o mundo. Aí está incutida a célebre frase de Arendt (2013) de que o amor à infância tem a ver com preparar as novas

3 Daí decorre o dizer: "faça o que você quiser, para mim tanto faz, porque apenas me importa agradas a mamãe natureza". 
gerações com tempo para a renovação do mundo humano comum, uma vez que, a escola existe para seja possível a comunicação/transmissão e renovação do mundo. Do mesmo modo, a autora adverte que quem "[...] se recusa a assumir a responsabilidade pelo mundo não deveria ter filhos nem lhe deveria ser permitido participar na sua educação" (ARENDT, 2013, p. 239).

Nessa direção, se os pais, professores e responsáveis não assumirem a tarefa de familiarizar os novos no legado humano, na herança simbólica, falham na própria especificidade de seus ofícios. $\mathrm{E}$, neste caso, constituem aquilo que denominamos de maus pagadores, uma vez que deixam os novos largados à própria sorte, sem apoio e o jugo adulto para conduzir e andar de mãos dadas. Isso, segundo Lajonquière (2009, p. 175), tem a ver com "[...] a renúncia dos velhos ao ato de educar [...] uma forma de infanticídio", alforriar/liberar uma criança, é impedi-la de viver a própria infância, de ser criança.

Uma criança cedo "liberada" dos adultos não é uma criança livre, mas uma criança sob influência[s] [...] ambientais, midiáticas, grupais, comunitaristas, tribais. Os pares não são melhores que os pais. O problema é que o afastamento do adulto leva a não se inscrever no laço intergeracional, a não se situar em uma história [comum], a crer que um presente, de resto preservado, pode e deve renegar o passado odioso para fecundar um futuro radiante. (GUILLOT, 2008, p. 27).

A responsabilidade dos adultos para com todos os novos e, também com aqueles que ainda chegarão neste mundo que faz surgir em sua própria dimensão a dívida simbólica. Nesse sentido, para Arendt (2013), a educação escolar proporciona aos adultos (pais e professores) de manifestarem o seu amor ao mundo e de se responsabilizarem por ele - o que corresponde ao conceito de amor mundi - além de amarem as crianças sem expulsá-las de seu mundo nem abandonálas à própria sorte ou aos seus próprios recursos, e de prepará-las e apoiá-las sem se apropriarem das possibilidades que elas terão de agir, de inovar, criar e de se responsabilizar pelo mundo que lhes é legado.

Aquele que opta em ser professor deve possuir um respeito extraordinário pelo passado, como lembra Arendt (2013), esse respeito se manifesta no esforço de iniciar e familiarizar as crianças ao mundo humano comum nas de tradições culturais cujo ensino lhe compete. Este é um dos aspectos centrais da concepção de educação nos estudos de Arendt (2013), já que no centro não está a criança, mas o mundo pelo qual todo adulto deve se responsabilizar e apostar por sua continuação por meio da familiarização e acolhimento dos recém-chegados em seu seio. A autoridade do professor funda-se, justamente, na responsabilidade que este assume pelo mundo e pelas crianças.

Portanto, a desresponsabilização pelo mundo e pelas crianças impossibilita a tarefa de educar. Logo, quando os adultos se desresponsabilizam, tornam-se maus pagadores, amputam todo conhecimento simbólico (filiação simbólica) que a educação escolar pode e deve oferecer a elas, sancionando-se, com isso, o abandono da própria infância, a corrupção das mentes infantis acerca da instituição escolar e do próprio mundo humano.

\section{ASSUMIR A DÍVIDA SIMBÓLICA: GARANTIA DO PASSADO NO FUTURO}

Toda criança que nasce é um novo ser humano e, ao mesmo tempo, um ser humano em formação/desenvolvimento. Por esse motivo que aqueles que já estão no mundo a mais tempo, se tornam responsáveis por apresentá-lo aos que nele estão adentrando, os recém-chegados. Os adultos são quem assumem na educação a responsabilidade pela formação e desenvolvimento da 
criança e pela durabilidade e continuidade do mundo humano comum. Trata-se, portanto, de uma responsabilidade dupla: face ao novo (criança) e ao mundo.

O fato de os recém-chegados aparecerem neste mundo como novos, exige dos adultos responsabilidade para acolher e familiarizar os novos com o mundo humano, pois, é essa familiarização que os tornará aptos a dominar, apreciar e transformar as tradições culturais que formam a herança simbólica comum e pública. É na possibilidade de assumir a responsabilidade pelos novos que reside a condição de que o mundo continue, dure e se aprofunde, a possibilidade de um (re)começo, de algo totalmente novo e imprevisível.

$\mathrm{Na}$ medida em que o recém-chegado não tem familiaridade com o mundo humano, é necessário introduzi-lo aos poucos nele. $\mathrm{Na}$ medida em que ele é novo, deve-se cuidar para que essa coisa nova chega à fruição em relação ao mundo como ele é (ARENDT, 2013). Trata-se, em outras palavras, de proteger "[...] a criança contra o mundo, o mundo contra a criança, o novo contra o velho, o velho contra o novo" (ARENDT, 2013, p. 242). O que é mais difícil, para Arendt, é amar o mundo como ele é. Amar o mundo significa o olhar inabalável e a compreensão daquilo que é.

A educação é, nessa direção, sempre uma aposta na imprevisibilidade. Essa aposta exige a preparação dos novos para que, futuramente, tenham condições de assumir a responsabilidade por esse mundo em que estão chegando e que auxiliarão na sua construção. Desse modo, não educamos as crianças apenas em função do processo vital ou para satisfazer seus desejos, mas principalmente para que no futuro possam fruir e recriar o mundo comum. Entretanto, primeiramente, sem ainda assumirem a responsabilidade por ele, precisam conhecê-lo. É nisso que consiste o ofício político da educação escolar. É através da educação escolar que o mundo se torna compreensível para a criança.

No entender de Arendt (2013), é especificidade da instituição escolar conservar e transmitir o legado histórico e cultural. Esse legado a que se refere a autora está contido no conhecimento ou conteúdo específico de cada disciplina que compõe o currículo escolar. Além disso, faz parte de sua função, como salientam González e Fensterseifer (2009, p. 18), “[...] preparar a passagem do privado (família) para o público (política/cidadania), viabilizando sua inserção e sua ação no mundo, por meio da qualificação da capacidade de interlocução, colocando-se à altura dos problemas de seu tempo".

Outrossim, é da especificidade da escola e do professor oferecer às novas gerações tudo o que elas devem aprender para que possam encontrar o seu lugar no mundo humano comum. E, para que isto ocorra, é preciso que a responsabilidade da escola e do professor pelas novas gerações e pelo conhecimento seja levada a sério. Só assim teremos, realmente, uma nova geração, capaz de modificar, aperfeiçoar e garantir a durabilidade e continuidade do mundo humano.

Nessa direção, referindo-se aos professores, Almeida (2011, p. 39) afirma que a autorização destes não é um atributo arbitrário, "[...] e não se origina em sua pessoa, mas nos saberes, nos valores e nos princípios do mundo comum e da instituição escolar que ele representa". Se compreendemos que a autoridade oferece "um passado para o futuro", então é possível considerar que ela ocupa um lugar destacado na educação. É desse modo que se salda a dívida simbólica.

Desse modo, a responsabilidade por parte do professor e de todos aqueles que são adultos e devem cuidar dos mais novos tem a ver, primeiramente, com o assumir a responsabilidade pelas crianças e, por conseguinte, pelo mundo comum em que estão a inserir estas. É por este motivo que a responsabilidade dos professores não está apenas no fato de que estes são responsáveis pelo crescimento e desenvolvimento dos alunos. Ela também reside no fato de que compartilham o mundo comum com eles, em suas diferentes dimensões e especificidades. Portanto, a educação escolar é a possibilidade de os professores e adultos manifestarem o amor ao mundo e de se 
responsabilizarem por ele; é a possibilidade de amarem as crianças sem expulsá-las de seu mundo nem as abandonar aos seus próprios recursos.

Assim sendo, a autoridade docente incide em fazer e autorizar a criança a crescer e protegêla até que seja capaz de responder por si, salvaguardando o seu bem-estar e a sua necessidade de proteção devido à sua fragilidade. A autoridade docente tem a ver com o responsabilizar-se pelo acolhimento e a preparação das novas gerações para com os princípios democráticos e republicanos da instituição escolar e da sociedade. A autoridade do professor na especificidade da educação escolar oferece aos novos as condições materiais e espirituais para que possam e consigam, quando adultos, assumir e desenvolver suas responsabilidades e iniciativas cidadãs.

Para Masschelein e Simons (2014), aceitar, cuidar, conservar e proteger o mundo implica radicalmente que é preciso também aceitar, cuidar e proteger as crianças como parte desse mundo comum, e isso significa colocar o mundo à disposição dos novos, expor o mundo, entregá-lo. Nessa perspectiva, os adultos são os representantes do mundo, são responsáveis pelo mundo e pelas novas gerações, e essa responsabilidade é uma atitude que preserva, conserva, admira e cuida as coisas do mundo comum. É tarefa dos mais velhos proteger, conservar e amar o mundo, mostrando as coisas valiosas para as crianças, como se dissessem aos novos: "isso é o nosso mundo, sintam-se em casa".

Os novos só poderão se sentir em casa neste mundo se os mais velhos se importarem com o mundo e com todos aqueles que aqui chegam. Ademais, para Arendt (2013, p. 247) a educação é

[...] o ponto em que decidimos se amamos o mundo o bastante para assumirmos a responsabilidade por ele e salvá-lo da ruína que seria inevitável não fosse a renovação e a vinda dos novos e dos jovens. A educação é, também, onde decidimos se amamos as nossas crianças, o bastante para não expulsá-las de nosso mundo e abandoná-las a seus próprios recursos [...].

Arendt coloca a educação escolar como transmissão do mundo comum, não como um modo de preparação para a vida ou como um adestramento em forma de vida, mas como um modo de transmitir o mundo. Uma transmissão que é, concomitantemente, uma conservação e uma renovação. Os recém-chegados são novos no mundo, vêm a um mundo que lhes precede e que irá lhes suceder, e a responsabilidade da educação escolar é lhes transmitir esse mundo, permitindo que os novos possam se sentir em casa nesse mundo.

Saldar a dívida possibilita a continuidade do mundo, o que não significa simplesmente uma espécie de adaptação ou então de socialização, mas, acima de tudo, em dar a continuidade a um mundo que já iniciou, inserindo nele os novos começos. Isso pelo fato de os novos adentrarem em um mundo pelo nascimento, sem saber ao certo como este começou e nem como terminará.

Brayner (2008), inspirado em Umberto Eco, afirma que vir ao mundo é como entrar numa peça de teatro depois de ter começado. Para participar do enredo, isto é, para se tornar um ator no palco do mundo público, é necessário saber o que ocorreu antes, qual o sentido da encenação e quais as regras a serem seguidas. Isso não significa que a peça siga um roteiro predeterminado, mas demanda que se ofereça aos recém-chegados condições mínimas de se orientarem, de atuarem no mesmo palco, inclusive, de darem novos rumos à peça. Nesse contexto, a educação escolar situaria as crianças, mostrando-lhes o que ainda não tiveram oportunidade de conhecer.

Assim sendo, os recém-chegados só podem vir a realizar novos começos no momento em que continuem aquilo que já está começado no mundo. Logo, podemos afirmar que os recémchegados não iniciam novos começos a partir do zero, do nada, mas, sobretudo, a partir de inícios já disponíveis no passado. Só assim que os novos poderão, então, responder aos começos do mundo, dando continuidade com os seus próprios começos. 
A recusa da autoridade na educação pode resultar no descaso - no não-saldar - para com a transmissão do legado simbólico capaz de dar durabilidade e sentido ao mundo comum. Furtarse da responsabilidade para com o mundo comum é abandonar as crianças (alunos) à própria sorte, sem o amparo da tradição e a familiarização com o legado cultural.

Nesse sentido, concordamos com Savater (2012, p. 38) que a primeira coisa que a educação transmite para cada recém-chegados "[...] é que não somos únicos, que nossa condição implica o intercâmbio significativo com outros parentes simbólicos que confirmam e possibilitam nossa condição". É esse conjunto de aspectos que define a existência histórica dos humanos - o artifício cultural, o artifício de um mundo humano que se aperfeiçoa e aprofunda continuamente. É por esse fato que, quando um adulto (pais, professores) oferece um fragmento cultural, uma possibilidade de ser influenciado pelo mundo, está abrindo a possibilidade de uma espécie de "[...] filiação simbólica" (LAJONQUIÈRE, 1999, p. 139), isto é, familiariza a criança com o legado humano. A educação escolar tem a ver com a possibilidade de se filiar a criança com o simbólico humanizante.

Portanto, para que os alunos consigam dar um novo significado, construir uma experiência, é preciso, como afirma Carvalho (2010), familiarizar os novos com as heranças históricas: a literatura, as artes, as ciências, a filosofia, os valores e as práticas sociais por meio dos quais foram legadas a compreensão do mundo e também a possibilidade do surgimento de novas formas de expressão. Ou, no entendimento de Arendt (2013), transmitir o legado consiste em legar uma herança e, por isso, os antecessores devem decidir o que e como entregar o seu legado para aqueles que chegarão.

Ademais, essa herança não se compõe apenas por aspectos materiais, mas inclui saberes e conhecimentos, princípios e compreensões. Arendt, como vimos, coloca a educação escolar como transmissão do mundo, não como preparação para a vida, ou como mero adestramento em forma de vida. Uma transmissão que é, ao mesmo tempo, conservação e renovação. A visão de discernir é um elo que liga uma geração à outra, algo que nós partilhamos com aqueles que viveram aqui neste mundo, mas em outro tempo.

Educar é transmitir marcas simbólicas que possibilitem ao pequeno sujeito gozar um lugar de enunciação no campo da palavra e da linguagem, a partir do qual lhe seja possível lançar-se às empresas impossíveis do desejo. O desdobramento de uma educação, de uma filiação simbólica de humanização e familiarização pressupõe que o adulto receba a criança como se fosse um estrangeiro, passível de se tornar mais ou menos familiar, mas nunca totalmente familiar (LAJONQUIÈRE, 2009).

\section{CONSIDERAÇÕES FINAIS}

Nós, adultos, somos os representantes do mundo, os responsáveis pelo mundo e pelas novas gerações. Essa responsabilidade tem a ver com preservar, admirar e cuidar das coisas do mundo comum. Por isso é preciso proteger, conservar e amar o mundo, mostrando as coisas valiosas para as novas gerações, dizendo: isso é o nosso mundo, sintam-se em casa aqui. É essa a tarefa de todo adulto, é assim que podemos saldar a nossa dívida.

$\mathrm{Na}$ educação escolar, especificamente, o professor tem a tarefa de familiarizar os novos com as heranças históricas: a literatura, as artes, as ciências, a filosofia, os valores e as práticas sociais por meio dos quais foram legadas a compreensão do mundo e também a possibilidade do surgimento de novas formas de expressão. Essa responsabilidade, no entender de Arendt (2013), assume forma de autoridade. A autoridade do professor, na especificidade da educação escolar, 
compete em oferecer aos novos as condições materiais e espirituais para que possam e consigam, quando adultos, assumir e desenvolver suas responsabilidades e iniciativas cidadãs.

Se o conhecimento e os saberes não operam no professor, tampouco o professor opera com o conhecimento e os saberes que precisa transmitir aos novos. Educar e instruir tem a ver com essa possibilidade de oferecer aos mais novos um testemunho acerca da própria aprendizagem, da própria elaboração e constituição do saber. É imprescindível, portanto, a interação social e cultural do professor, pois esta possibilita a continuidade do mundo comum de uma geração para outra. Afinal, não soa estranho o professor querer conduzir os alunos por caminhos que ele próprio não tenha passado ou aprendido?

Nessa direção, a escola se configura como criação recente, capaz de manter o elo entre as gerações, de introduzir as novas gerações no legado da humanidade. Para que sua especificidade possa ser garantida e realmente efetivada, ela precisa se resguardar das necessidades exteriores e demandas de outra ordem - econômica, política, religiosa etc. É de sua especificidade saldar a dívida simbólica através do ensino, da transmissão, e da apresentação do conhecimento acumulado pela humanidade. Lembramos que a transmissão cultural é constitutiva das sociedades humanas, já que ela possibilita novos inícios dentro da teia de relações que configura a nossa existência no mundo humano comum.

Quando Arendt (2013) coloca a educação escolar como transmissão do mundo humano, significa que esta não tem a ver com a preparação para a vida, mas com a ideia de conservação e de renovação. As crianças que nascem são novas no mundo, pois vêm a um mundo que lhes precede e que seguramente irá lhes suceder, logo, a educação escolar tem a tarefa de lhes transmitir esse mundo, de entregá-lo como uma herança, mesmo que seja uma herança sem testamento ${ }^{4}$. Isto é, os novos renovam o mundo ao mesmo tempo que o recebem. A transmissão dos saberes e conhecimentos permite que algo permaneça justamente para que possa ser renovado e não se perca irremediavelmente, é assim que possibilitamos um passado para o futuro.

Toda construção da cultura supõe que os criadores (científicos, artísticos, filosóficos) comunicam entre pares (correspondências, via internet, revistas, jornais, artigos, eventos) e comunicam à humanidade, ao público em geral. Sem essa comunicação entre as gerações, e que a escola também proporciona, esse elo da criação cultural não se manteria. Só essa comunicação entre gerações pode fazer com que cada criança participe do mundo que os humanos construíram, modificaram e aperfeiçoaram.

Ademais, só a escola inscreve no sempre caminhar para diante da condição humana, o retorno, o regresso ao legado cultural do passado e, assim, dá continuidade ao elo da criação, o saldar da dívida simbólica para com os novos. Por isso, todo aquele que entra e sai da escola se constitui em um sucessor, alguém que herda do passado, alguém que o sucede, que vai atrás, à raiz, ao início, à fonte, e que, por isso, somente por isso, está em condições de continuar, de construir um futuro. É isso que esperamos de um professor, de uma escola e de uma sociedade preocupada e responsável com o mundo comum e as novas gerações.

\section{REFERÊNCIAS}

\footnotetext{
${ }^{4}$ Significa dizer que a herança não acompanha nenhum testamento (instruções ou técnicas), não há um manual de instruções. O que os adultos fazem - deveriam fazer - é apresentar o legado para as novas gerações a fim de que se torne possível interpretá-lo, e assim, cada nova geração deverá prestar contas com a herança e aquilo que lhes foi legado.
} 
ALMEIDA, Vanessa Sievers de. Educação em Hannah Arendt: entre o mundo deserto e o amor ao mundo. São Paulo: Cortez, 2011.

ARENDT, Hannah. Entre o passado e o futuro. Tradução de Mauro W. Barbosa. 7. ed. São Paulo: Perspectiva, 2013.

BRAYNER, Flávio. Educação e republicanismo: experimentos arendtianos para uma educação melhor. Brasília: Liber Livro, 2008.

CARVALHO, José Fonseca de. A liberdade educa ou a educação liberta? Uma crítica das pedagogias da autonomia à luz do pensamento de Hannah Arendt. Educação e Pesquisa, São Paulo, v. 36, n. 3, p. 839-851, set./dez. 2010.

GUILLOT, Gérard. O resgate da autoridade em educaşão. Tradução de Patrícia Chittoni Ramos Reuillard. Porto Alegre: Artmed, 2008.

KANT, Immanuel. Sobre a pedagogia. Tradução de Francisco C. Fontanella. 2. ed. Piracicaba: Editora Unimep, 1999.

LAJONQUIÈRE, Leandro de. Infância e ilusão (psico)pedagógica: escritos de psicanálise e educação. Petrópolis: Vozes, 1999.

LAJONQUIÈRE, Leandro de. Educação e Infanticídio. Educação em Revista, Belo Horizonte, v. 25, n. 1, p. 165-177, 2009.

LARROSA, Jorge. Esperando não se sabe o quê: sobre o ofício de professor. Tradução de Cristina Antunes. Belo Horizonte: Autêntica Editora, 2018.

MALAGUZZI, Loris. História, ideias e filosofia básica. In: EDWARDS, C.; GANDINI, L.; FORMAN, G. (org.). As cem linguagens da criança: a abordagem de Reggio Emilia na educação da primeira infância. Porto Alegre: Artmed, 1999.

MASSCHELEIN, Jan; SIMONS, Maarten. Em defesa da escola: uma questão pública. Tradução de Cristina Antunes. 2. ed. Belo Horizonte: Autêntica, 2017.

MASSCHELEIN, Jan; SIMONS, Maarten. A pedagogia, a democracia, a escola. Belo Horizonte: Autêntica, 2014.

ROGERS, Carl. Liberdade para aprender. Minas Gerais: Entrelivros, 1971.

SAVATER, Fernando. O valor de educar. Tradução de Monica Stahel. 2. ed. São Paulo: Planeta, 2012. SCHÜTZ, Jenerton Arlan. Consequências de uma educação facilitadora. RevistaDi@logus, Cruz Alta, v. 6, n. 2, p. 44-63, maio/ago. 2017.

\section{Informações do(a)(s) autor(a)(es)}

Jenerton Arlan Schütz

Universidade Regional do Noroeste do Estado do Rio Grande do Sul, Ijuí, RS, Brasil.

E-mail: jenerton.xitz@hotmail.com

ORCID: http://orcid.org/0000-0002-3603-7097

Link Lattes: http://lattes.cnpq.br/6075418179655079 
Fábio César Junges

Universidade de Cruz Alta, Cruz Alta, RS, Brasil.

E-mail: fabiocesarjunges@yahoo.com.br

ORCID: http://orcid.org/0000-0002-7412-9566

Link Lattes: http://lattes.cnpq.br/2904093017765049 